\begin{tabular}{lll} 
KULTURA & $\begin{array}{l}\text { POLSKA A KADEMIA NAUK } \\
\text { KOMITET SOCJOLOGII }\end{array}$ & ISSN 0023-5172 \\
i & $\begin{array}{l}\text { INSTYTUT STUDIÓW POLITYCZNYCH } \\
\text { SPOLECLENSTWO }\end{array}$ & \\
\hline 2017, nr $3 \quad$ AUTOETNOGRAFIA &
\end{tabular}

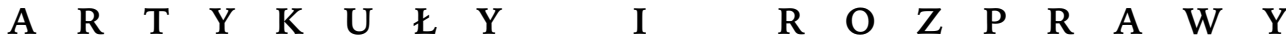

KATARZYNA KALINOWSKA

Uniwersytet Warszawski

\section{O AUTOETNOGRAFII DOTKNIĘĆ, ZRANIEŃ I ODKSZTAŁCEŃ}

\section{BADACZ JAKO CZĘŚĆ METODY}

Stanisław Ossowski (2001, s. 13) rozważania o zagadnieniu introspekcji rozpoczął od krótkiego przeglądu stanowisk filozoficznych w kwestii statusu doświadczeń wewnętrznych w epistemologii. Przypomniał: „[...] zawsze zdawano sobie sprawę, że kiedy przedmiotem obserwacji staje się własna osoba, obserwator znajduje się $\mathrm{w}$ położeniu wyjątkowo uprzywilejowanym: nikt inny nie ma takiego dostępu do jego przeżyć, jak on sam". W podobnym duchu ponad trzy dekady wcześniej wypowiadał się Florian Znaniecki na kartach Metody socjologii (2009, s. 186), ujmując sprawę autoobserwacji następująco: „Osobiste doświadczenie badacza stanowi naczelne i najbardziej wiarygodne źródło informacji w socjologii, tak samo jak w każdej innej nauce, jakkolwiek jest ono w naturalny sposób ograniczone. Zarówno jego wiarygodność, jak i ograniczenia wydają się tak oczywiste, że trudno pojąć, jak kiedykolwiek mogły się pojawić szkoły myśli naukowej, które albo zupełnie je odrzucają, albo przeciwnie, wychwalają je jako całkowicie samowystarczalne źródło danych socjologicznych". Tymczasem oczywistość powyższych twierdzeń nie jest wcale bezsporna, odkąd pozytywistyczne nastawienie sprawiło, że „[...] nauka stała się nowym typem doświadczenia, legitymizującym poznanie pośrednie" (Badura 2015, s. 19). To, co pokoleniom filozofów oraz socjologów o orientacji fenomenologicznej wydawało się jasne, czyli ustalenie, że „jedynym momentem rzeczywistości, zna- 
nym mi bezpośrednio, jedynym punktem, w którym docieram do «rzeczy samej w sobie» nie przesłoniętej powłoką zjawisk, jestem ja sam" (Badura 2015, s. 13-14), nie znalazło aprobaty ani kontynuacji w behawioralnych naukach społecznych czy w nurtach psychoanalitycznych, na których z kolei w dużej mierze opierają się główne paradygmaty we współczesnych naukach społecznych. Szkoła durkheimowska (zwana niekiedy pardygmatem faktu społecznego), funkcjonalizm, behawioryzm, ewolucjonizm, a wraz z nimi nauki społeczne o modelu scjentystycznym, ilościowe i eksperymentalne, negują wartość działań introspekcyjnych jako niemożliwych do zewnętrznej weryfikacji i kreujących artefakty poprzez ingerencję w kształt badanej rzeczywistości. Takie stanowisko „odcina" podmiotowego badacza od kanałów wytwarzania wiedzy naukowej. Z kolei psychoanaliza, ujęcie marksistowskie, a z nimi teorie konfliktu, nurt badań tekstualnych, ale także strukturalizm również kończą z myśleniem o podmiocie samoświadomym i zdolnym do samopoznania, wprowadzając do słownika naukowego pojęcia takie jak: podświadomość, ukryte motywy i znaczenia, głębokie struktury, świadomość dziejowa (ponadjednostkowa), władza tekstu czy dyskursu itp., które — jako zamknięte przed świadomością — winniśmy zgłębiać niejako poza podmiotem. Ponieważ „człowiek jedynie myśli, że myśli, a w gruncie rzeczy jest on myślany przez struktury” (Badura 2015, s. 33). Nurty te nie odżegnują się wprawdzie od metody wglądu, ale często jej nadużywają. To nadużycie polega na tym, że badacz „zamiast wykorzystywać w swojej refleksji fakty takimi, jakie je znajduje, wymyśla nowe fakty w toku swojej refleksji" (Znaniecki 2009, s. 189), odrzuca to, co bezpośrednio dostępne, i nadbudowuje rzeczywistość $\mathrm{w}$ poszukiwaniu podświadomych doświadczeń i głębszych struktur. Świadome posługiwanie się introspekcją na gruncie nauki było zatem krytykowane bądź za „nienaukowy”, „nieprofesjonalny” charakter, bądź za niedostateczną skuteczność poznania.

Konsekwencją odrzucenia bezpośredniego doświadczenia jako źródła wiedzy naukowej i ośmieszenia introspekcji w akademickim badaniu człowieka — jego świata psychicznego i świata społecznego - są dwie, święcące dziś triumfy, redukcjonistyczne tendencje w naukach społecznych. Pierwsza to niezwykle silne przekonanie o istotności i trafności interpretacji i wnioskowań $\mathrm{w}$ autoreferencyjnych naukach empirycznych, które odwołują się do samych siebie (jako logicznych, zamkniętych systemów wiedzy, w odróżnieniu od nielogicznych rozumowań potocznych czy niedomkniętych konceptualnie „gatunków zmąconych" we współczesnych naukach interpretatywnych, por. Denzin 1997; Bielecka-Prus 2012), nie konsultując swoich teorii z dyskursami pozanaukowymi. Drugą tendencją jest uparte dążenie do odnajdowania w świecie życia i odczytywania w tekstach kultury ukrytych, niejawnych, nieuświadomionych, niezamierzonych, nieintencjonalnych motywów działań i takiej interpretacji, by można było na tym oprzeć całą wiedzę naukową o świecie społecznym. Wynika to z przekonania o tym, że natura człowieka oraz mechanizmy funkcjonowania świata są niedostępne podmiotowemu poznaniu, ale podlegają pozna- 
niu naukowemu. Takimu myśleniu towarzyszy wiara $\mathrm{w}$ realną możliwość niedeformującego udyskursowienia „rzeczy samych w sobie”, tego, co faktycznie przeżywane (choć niekoniecznie dyskursywnie interpretowane przez sam podmiot), oczywiste, przedrefleksyjne, realizujące się w świadomości praktycznej, a być może po prostu niedyskursywne. Prowadzi to często do nainterpretowania tekstów i zjawisk kulturowych. W obydwu przypadkach następuje odejście od bezpośredniego, podmiotowego doświadczenia.

W tych modelach uprawiania nauki nie było i wciąż nie ma miejsca dla podmiotowego badacza ${ }^{1}$. Jednak badacz jest częścią metody. Zawsze był, nawet wówczas, gdy reprezentanci nauk społecznych i humanistycznych, wiedzeni scjentystycznym ideałem nauki, upatrywali „naukowości” swoich dyscyplin w „obiektywności” i „pewności” wytwarzanej przez siebie wiedzy. „Obiektywność” zaś miało gwarantować całkowite wyłączenie „czynnika ludzkiego” z procesu badawczego, zanegowanie wpływu osoby badacza na rezultaty jego pracy naukowej. Metodologicznymi wymogami były intersubiektywna komunikowalność i weryfikowalność rezultatów badań, a strażnikiem tak uprawianej nauki — oświeceniowa racjonalność. Badacz był niezależnym podmiotem poznającym, neutralnym, „niewinnym” obserwatorem, a jednocześnie jego perspektywa, język, system pojęciowy były nadrzędne wobec perspektyw badanych. Empiryczna nauka społeczna miała opierać się na „doświadczeniu o charakterze publicznym" (eksperymenty i obserwacje), a - jak pisał Karl Popper (1985, s. 433; por. Durkheim 2000) — „doświadczenie jest publiczne, jeśli każdy, kto zada sobie trud, może je powtórzyć”.

Od przełomu antypozytywistycznego w filozofii i socjologii (przełom XIX i XX wieku) ów wymóg „obiektywności” w naukach społecznych zaczyna być zastępowany przez dyskusje o „relatywnej mądrości” versus „obiektywnej pewności” (Weber 1985a; Badura 2015; Rorty 2009, 2013). Tendencję taką wzmocniły kontrowersje wokół zwrotu lingwistycznego w humanistyce (pierwsza połowa XX wieku), dyskusje na temat konstruowania świata przez użycia języka, ugruntowanie podejścia relatywistycznego w badaniach kultury (zob. Rorty 2009, s. 243-265). Odegrało to również kluczową rolę w zmianach w obrębie antropologii, otwierając droge późniejszym falom samokwestionowania dyscypliny (zob. Denzin 1997; Kuligowski 2012; Rabinow 1999; Walczak 2009; 2013). „Obiektywność” zaczyna być inaczej definiowana - wymaga uwzględniania ograniczeń wynikających z kulturowych bądź indywidualych uwarunkowań, kontekstów, założeń i rozstrzygnięć leżących u podstaw tez stawianych przez badacza, aby móc nauki społeczne „uwolnić od wartościowan” — na tym podejściu ufundowany jest paradygmat humanistyczny w socjologii (Weber 1985a, 1985b), a po części także późniejsza postmodernistyczna i postkolonialna krytyka w antropologii. Badacz ma być świadomy swojej perspektywy,

${ }^{1}$ Jak również dla podmiotowego badanego. 
ale wciąż niezależny, a jako taki nie powinien przedkładać, uwidaczniać własnej perspektywy na drodze poznania opartego na rozumieniu. Jednak „[...] zachowanie obiektywności, rozumianej jako niezależność punktów widzenia i pozanaukowych interesów, łączy się z koniecznością rozgraniczenia sfery opisu i eksplantacji oraz sfery ocen" (Badura 2015, s. 18). Pokazuje to, że w wyniku zmiany myślenia o możliwościach poznania świata społecznego badani i badacz zyskują, co prawda, podmi o tow ość, ale w obrębie wczesnej socjologii rozumiejącej propozycje metodologiczne nie mówią jeszcze o sprawstwie badacza. „Obiektywność”, choć już rozłączna z „pewnością” wiedzy naukowej, wciąż znaczy, że badacz ma, na ile to możliwe, uczynić siebie „przezroczystym”, aby nie przesłonić swoją obecnością właściwego przedmiotu badań i móc „poznać badanych lepiej niż oni sami siebie znają”. „Obiektywność” wyraża się więc wówczas w dystansie wobec badanego świata poprzez „całkowite zawieszenie na czas badania subiektywnie naznaczonych dyspozycji” (Badura 2015, s. 36).

Dopiero stopniowo, w miarę rozwoju fenomenologii społecznej (Schütz 1984), konstruktywizmu społecznego (Berger, Luckmann 1983) i interakcjonizmu symbolicznego (Blumer 2007) oraz antropologii interpretatywnej (Geertz 2005a, 2005b), a najbardziej intensywnie wraz ze zwrotem performatywnym w humanistyce (lata osiemdziesiąte XX wieku; zob. Domańska 2007; Kowalewski, Piasek 2010), w procesie naukowym pojawiało się miejsce dla badacza nie tylko jako wykonawcy procedur badawczych, „człowieka bez właściwości”, ale także jako konkretnej osoby sprawczej, która jest badaczem na swój własny sposób, dzięki temu, że jest sobą i doświadcza jako ona (zob. Behar 1996; Hastrup 2008; Merleau-Ponty 2015; Mokrzycki 1984; Rakowski 2009). To kolejny krok w redefiniowaniu „naukowości”, gdyż — jak słusznie podsumowuje Marta Rakoczy $(2014$, s. 7) — „[...] celem zwrotu performatywnego jest nie tylko przywrócenie sprawczości uczestnikom kultury ujmowanym dotychczas jako podmioty pozostające we władzy tekstu, dyskursu czy stosunków wiedzy/władzy. Jego celem ma być także nadanie sprawczego charakteru samej działalności naukowej postrzeganej odtąd nie jako bierna kontemplacja, lecz aktywna, dążąca do zmiany rzeczywistości kulturowej interwencja. Jako taki zwrot ten nie oznacza jedynie zaangażowania nauki. Oznacza wyjście poza tradycyjne dychotomie separujące fakty i wartości, teorię i praktykę, w końcu zaś naukę i sztukę".

Miejsce i rola badacza $w$ procesie badawczym zmieniała się wraz z rozwojem metodologii nauk społecznych. Można zauważyć, że zmiany te przebiegały niejako dwutorowo. Jeśli chodzi o u prawomocnienie aktywnej obecności badacza jako konkretnej osoby w terenie i w tekście, to badacz przesuwa się stopniowo, acz konsekwentnie, z peryferiów do centrum interakcji badawczej. Od enigmatycznej postaci, która fizycznie ,jest, ale jakoby jej nie było", a na pewno nie ma jej tam, gdzie tworzą się sensy i odtwarzają znaczenia życia codziennego; przez badacza, który poprzez empiryczne doświadczenie ma bezpośredni dostęp do badanej rzeczywistości, ale sam jest 
niedostępny (nie dotyka rzeczy w sposób najbardziej bezpośredni z możliwych - we własnym doświadczeniu wewnętrznym); po partnera interakcji, który doświadcza, dzieli się z badanymi swoim spojrzeniem, wymienia perspektywy, odkrywa siebie.

Z wyraźnym opóźnieniem względem tych przemian ulega przeformułowaniu kwestia władzy badacza nad procesem interpretacji. Tu równolegle rozwijają się dwa główne nurty ${ }^{2}$. W pierwszym stawia się język, system logiczny i pojęciowy, jakimi posługuje się badacz — przedstawiciel świata nauki, ponad potoczymi sensami i racjonalnościami wyrażonymi potocznym językiem według potocznej logiki rozumowania (zarówno własnej, jak i Innych). $\mathrm{Tu}$ „totalna” władza badacza-profesjonalisty i jego dyscypliny naukowej uwidacznia się w tekście, w akcie pisania. W drugim nurcie „robienia antropologii” równie uprawnione są różne narracje i metaforyki - lokalne, osobiste, profesjonalne - badacz z nich czerpie, ale nie tyle oddaje głos badanym, ile czasem sam zmuszony jest walczyć o swój głos, swoją interpretację. Badacz bowiem ,[...] nie jest po prostu doznającym człowiekiem, który dzieli się z innymi swoimi przygodami; jest raczej osobą szczególną, posiadającą kompetencje teoretyczne i analityczne, które pozwalają mu - mniej czy bardziej in statu nascendi - ująć badane odczucia w kategoriach konkretnej teorii" (Łukasiuk 2012, s. 84). Język opisu tworzy się więc zarówno w doświadczeniu lektury i myślenia teoretycznego (które należą do najbliższych, najbardziej dostępnych, codziennych doświadczeń badacza; zob. Mills 2007), jak i w interakcji, w działaniu - w życiu codziennym, które polega na spotkaniu z Innym i dzieleniu $z$ nim przestrzeni komunikacji. W takiej perspektywie - bliskiej mojemu podejściu do działalności badawczej — „możliwe jest umieszczenie tej pierwotnej komunikacji, współbycia etnografa i innych ludzi w centrum terenowej praktyki" (Rakowski 2009, s. 30).

W każdym przypadku — jeśli idzie o operowanie zarówno swoją osobą, jak i własnymi bądź naukowymi interpretacjami w interakcji i w tekście — konieczna jest duża doza refleksyjności i samoświadomości badawczej. I w tym miejscu pojawia się temat autoetnografii, która przybiera kształt metody.

\section{AUTOETNOGRAFIA, CZYLI ODROBIONA LEKCJA}

Została przełamana tendencja, zgodnie $\mathrm{z}$ którą $\mathrm{w}$ nowożytnej filozofii i humanistyce "pragnienie pewności” zwyciężało nad „potrzebą mądrości”

\footnotetext{
${ }^{2}$ Istnieje też trzecie stanowisko, skrajnie postmodernistyczne, pozostające na marginesie akademickiej antropologii. Stawia ono wiedzę badanych i lokalne dyskursy ponad dyskursem antropologicznym i wiedzą badacza, który właściwie staje się jedynie skrybą i tubą dla wiedzy lokalnej. To stanowisko cały akcent kładzie na tekstualny wymiar antropologii (wiedza lokalna, narracja badanego przyjęta bezkrytycznie jest jedynym, najbardziej uprawnionym dyskursem), odbiera jakąkolwiek prawomocność i siłę doświadczeniu etnograficznemu (zob. Rakowski 2009).
} 
(Rorty 2013) ${ }^{3}$. Dyskusję o „obiektywności” zastąpiła dyskusja o „autentyczności”. Osobowy, „nietransparenty” badacz zagrażał „pewności” i „obiektywności”, „mądrości” i „autentyczności” nie zagraża. Przeciwnie, badacz jakościowy - poprzez osobiste, autentyczne doświadczanie terenu - mówi „sprawdzam” potocznym mądrościom i przedsądom, rozumowaniom i wrażliwościom, racjonalnościom i wierzeniom, teoriom i praktykom, zarówno tym, które obserwuje wkraczając $\mathrm{w}$ teren, jak i tym, które stanowią jego własną wiedzę podręczną, własny habitus. Jest przy tym zdolny podważać oczywistość badanych światów życia i poddawać je fenomenologicznemu rozumieniu właśnie dlatego i tylko dlatego, że posiada swoje własne potoczne mądrości i przedsądy, rozumowania i wrażliwości, racjonalności i wierzenia, teorie i praktyki; dlatego, że ma wgląd w swoje doświadczenie życia. W antropologii i socjologii interpretatywnej umiejętność podważania oczywistości i dystansowania się (od „obcości”, ale również od „swojskości”) w różnych wymiarach życia (umysłowego i zmysłowego), umiejętność szukania zgrzytów i sprzeczności (Kaufmann 2004, 2010) jest bowiem tym, co umożliwia badaczowi poznanie naukowe. Uzmysławia istnienie wielości rzeczywistości, z których każda konstruowana jest jako oczywista i obiektywna (Manterys 1997). Pozwala dostrzec różnicę i brak różnicy, a w konsekwencji uzyskać biegłość w przekładaniu perspektyw - procesie fundamentalnym dla rozumienia (Schütz 1984; Berger, Luckmann 1983). Przekładalność perspektyw nie jest możliwa bez zabiegu, jakim jest zarzucenie własnej perspektywy, pewnego rodzaju „wyjście poza siebie” — a także spojrzenie na siebie samego po tym, jak już „się z siebie wyjdzie”.

Badacz rozumiejący musi więc najpierw zrozumieć własną perspektywę, umieć się od niej zdystansować, aby móc z niej korzystać. „Badacz bez właściwości" - niewidoczny jako aktor w badawczej interakcji — nie dotknie i nie opowie badanej rzeczywistości społeczno-kulturowej (a czym innym zajmują się antropologia i socjologia?), gdyż bez materiału porównawczego, jakim jest jego własna perspektywa, nie będzie umiał wyczuć i zintegrować światów, sensów i znaczeń. Idąc za fenomenologią Maurice’a Merleau-Ponty'ego, można powiedzieć, że „inny człowiek pozostanie rzeczywiście «innym» tylko wtedy, gdy pozostanie takim, jakim jest — samym sobą" (Rakowski 2009, s. 31; por. Merleau-Ponty 2015, s. 85-90). To się tyczy również badacza „robiącego antropologię”, który „pracuje” różnicą i innością. Najlepszym narzędziem hermeneutycznym jest więc sam czujący i autorefleksyjny badacz. Jeśli bada on „obcy" świat, będąc (o) sobą, może wychwycić to, co w związku z jego obecnością jest dla badanych inne, nie-swojskie, nie-oczywiste. Może dzięki temu zrozumieć, co różnicuje praktyki, co jest unikalnym sednem doświadczenia, dystynk-

${ }^{3}$ Cechujące filozofię przednowoczesną (przedkartezjańską) poszukiwanie mądrości, o czym pisze Rorty, to poszukiwanie obiektywnej (prawdziwej) mądrości. Zgodnie ze współczesną myślą humanistyczną możemy mówić raczej o mądrości relatywnej, o ukontekstowionych mądrościach. 
cją w stylach życia itd. Gdy bada świat „swój”, różnicę dostrzega w zmianie, jaką jest (lub nie jest) w stanie przejść dzięki zaangażowaniu siebie jako osoby w proces obserwacji, pozwalając Innym naruszyć swoje granice pojmowania świata i wrażliwości, podważyć to, co dla niego oczywiste (zob. np. Kleszcz 2004; Olejnik 2007). W takim układzie „nietransparentny”, zwrócony ku sobie badacz nie tylko nie zagraża „naukowości” antropologii czy socjologii, ale staje się po prostu niezbędny, aby te dyscypliny mogły się rozwijać i pełnić swoje role w warunkach poszerzenia granic tego, co publiczne i społeczne, w obliczu zwrotu ku emocjom i przeżywaniu (por. Łukasiuk 2012, s. 72-74).

Podobnie z perspektywy rozwoju antropologii - szukanie przez współczesnych badaczy jakościowych metodologicznego wsparcia w autoetnografii to odrobiona lekcja $z$ antropologii, którą zwrot lingwistyczny jako pierwszą „pchnął [...] do budowania samorefleksyjności jako warunku sine qua non rzetelnego uprawiania nauki" (Walczak 2013, s. 111). Ojcowie założyciele antropologii akademickiej, antropologowie epoki kolonialnej, przedstawiciele „etnografii realistycznej" - piszący niby o Innych, a tak naprawdę o kulturze zachodniej (czyli de facto o sobie), „prześwitujący” przez własne teksty — ostatecznie dali się obnażyć, pozostawiając w swoim pisarstwie furtki umożliwiające zakwestionowanie ich autorytetu etnograficznego ufudowanego na założeniu o „obiektywności” nauk antropologicznych. Krytyce zostały poddane także przedstawiane środowisku naukowemu i opinii publicznej świadectwa kolejnych pokoleń etnografów, takie jak Margaret Mead o dojrzewaniu na Samoa, Marshalla Sahlinsa o śmierci kapitana Cooka czy Napoleona Chagnona o Yanomami (zob. Kuligowski 2012, s. 18-20). Antropologowie epoki ponowoczesnej, jak Clifford Gertz w esejach z klasycznej już pracy Dzieło $i$ życie (2000) i wielu kontynuatorów antropologii postmodernistycznej (zob. Buchowski, Kempny 1999; Clifford, Marcus 1986; Clifford 2000), ochoczo podjęli owe tropy, głosząc kryzys przedstawiania i konieczność tekstualizacji w antropologii. Tradycyjnych i modernistycznych antropologów, o ugruntowanej w ówczesnej nauce pozycji neutralnych badaczy-outsiderów, zdradziły „teksty nasycone autorem” (Geertz 2000, s. 19), nie opatrzone rzetelną notą autoetnograficzną, pełne za to „egocentrycznego ja” zachodnich uczonych.

Jednak choć narracje o „dzikich” Bronisława Malinowskiego, Margaret Mead czy Claude'a Lévy-Straussa dziś nie w każdym punkcie się bronią, to ich teorie wciąż są intelektualnie płodne i obecne w refleksji antropologicznej. Duża w tym zasługa faktu, że „wielka antropologia modernistyczna" została obudowana ponowoczesną refleksją o badaczu-autorze. Krytyczna refleksja zastąpiła brak uporządkowanych autoetnograficznych odniesień w samych dziełach. Dokonała „ugruntowania ważności i pewności procedur oraz wyników poznania naukowego nie w konwencji, sile autorytetu" (Badura 2015 , s. 28), jak zostało to uczynione w tekstach. Musiały zostać one opatrzone notami metodologicznymi, dopisanymi przez postmodernistycznych dekonstruktorów, aby przekształcić autorytet etnograficzny autorów 
w ten budowany na autentyczności nieprzejrzystego tekstu, a nie na obiektywności przejrzystego badacza. I choć owa krytyczna refleksja odnosiła się właściwie wyłącznie do warstwy tekstów, literackich dyskursów antropologicznych - a pozostawanie w ramach dyskursu, jak zauważa Wojciech Burszta (1993, s. 195), niechybnie wiąże się z rezygnacją z kontroli rzeczywistości - to można śmiało zaryzykować stwierdzenie, że zwrot tekstualny w pewnym sensie przekonstruował wartość klasyki antropologicznej.

Dzisiejsza krytyka antropologiczna domaga się nie tylko analizowania podmiotowości badacza-autora, zwornika interpretacji, ale także pokazania całej rozciągłości jego obecności i aktywności $\mathrm{w}$ terenie i $\mathrm{w}$ tekście, a więc uznania sprawstwa badacza i performatywnego (nie tylko tekstualnego) charakteru humanistyki (zob. Denzin 1997; Holman Jones 2009; Bielecka-Prus 2012; Kafar 2010). I możliwości zbudowania autorytetu etnograficznego na autentyczności refleksyjnego, wrażliwego, samoświadomego badacza.

Ten trwający już ponad pół wieku proces samokwestionowania antropologii $^{4}$ to raczej sposób trwania dyscypliny niż źródło kryzysu, ponieważ „[...] historię każdej dyscypliny akademickiej tworzą nie tylko nazwiska wielkich teoretyków, wybitnych badaczy, wpływowe teorie i przełomy metodologiczne, ale także reinterpretacje dotychczasowego dorobku, krytyczne odczytania poprzedników, schizmy, zerwania i kontrowersje" (Kuligowski 2012, s. 17). Paradygmat badań etnograficznych znalazł się więc $\mathrm{w}$ takim punkcie, $\mathrm{w}$ którym antropologowie odrobili już tę lekcję i łączą role badacza-autora i swojego własnego refleksyjnego krytyka. Status oczywistości przyjmują dziś twierdzenia, że w naukach humanistycznych i społecznych „[...] względna obiektywność wyłania się dzięki świadomości własnych kulturowych ograniczeń, zanurzeniu w sądach wartościujących czy strukturach myślowych, których nierzadko nie jesteśmy świadomi [...]”, i w związku z tym „[...] poddanie refleksji tego, że badacz niesie ciężar kulturowych przekonań, jest kluczowe do zrozumienia innej kultury" (Kossakowski 2014, s. 98). W ten sposób autoetnografia stała się integralną (choć niejednorodną) częścią metodologii badań jakościowych.

\section{„BADACZ JAKO NARZĘDZIE”}

Współcześnie zatem świadomość metodologiczna antropologów i socjologów jakościowych nie pozwala im ignorować roli badacza (jako kon-

\footnotetext{
${ }^{4}$ Można powiedzieć, że socjologia, jako dyscyplina w nieustannym kryzysie, uznaje za stan naturalny „przerost refleksji i samokrytycyzmu” (Szacki 1977, s. 6). Natomiast w antropologii, która budowała od początku istnienia dyscypliny swój mocny status „królowej nauk”, rozmaite kryzysy — reprezentacji, legitymacji, praktyki - postrzegane są przez niektórych badaczy jako symptomy czy przyczyny kryzysu dyscypliny antropologicznej (zob. Kuligowski 2012; por. Denzin 1997).
} 
kretnej osoby) w procesie badawczym. Nie chodzi tu już wyłącznie o wskazanie wpływów, jakie może wywierać badacz (każdy, ktokolwiek) na poznawaną rzeczywistość, zniekształcając ją i/lub przekształcając. Te wpływy nadal często są postrzegane jako ogólna słabość metod jakościowych i etnograficznych (zob. Babbie 2004; Silverman 2010) ${ }^{5}$, ale jednocześnie podnoszone są jako ich wartość, zwłaszcza w performatywnych nurtach antropologii zaangażowanej (Rakowski 2013), etnografii interpretacyjnej (Denzin 1997; Bielecka-Prus 2012) czy autoetnografii ewokatywnej (Holman Jones 2009; Kacperczyk 2014; Kafar 2009). Chodzi o „nieprzezroczystą” obecność badacza (tej, a nie innej osoby), czyli przede wszystkim jego udział w procesach poznawczych, zarówno na etapie stawiania problemów badawczych, pozyskiwania danych, tworzenia kluczy do analizy materiałów, jak i teoretycznych interpretacji oraz samego pisarstwa. Wszystkie te czynności są wykonywane przez osoby, które mają konkretne doświadczenia, indywidualne predyspozycje i swoiste zasoby wiedzy podręcznej, tak ważnej w naszej profesji - jednym słowem, każdy badacz ma inne, wyjątkowe drogi dostępu do znaczeń i sensów w badanym świecie. I choćby dlatego „antropologicznych rozmów i interakcji w terenie nigdy nie uda się w sposób dokładny powtórzyć" (Behar 1996, s. 7), antropologia zawsze będzie opowieścią o konkretnym doświadczeniu, próbą odszukania struktury sensów w strukturze tego doświadczenia. „Doświadczenie jest zawsze doświadczeniem czegoś, a wcześniej: doświadczeniem czyimś, stąd też $\mathrm{w}$ nauce wykształciła się również nowa koncepcja podmiotu poznającego i jego możliwości" (Badura 2015, s. 19). Doświadczenie zawsze zatem pozostanie udziałem konkretnego badacza - i to od niego trzeba zaczaćc. Gdy spojrzymy na badacza jak na unikalne narzędzie badawcze, które jest w stanie dotrzeć do takich pokładów wiedzy, do których nie sięgnie najlepiej skonstruowane „martwe” narzędzie (a często również inny badacz), jego obecność $\mathrm{w}$ procesie badawczym może stać się atutem, kluczem, szansą. Są bowiem takie obszary świata przeżywanego (nieuspołecznione?), do których pozwala dotrzeć wyłącznie „dostęp osobisty”. Dlatego, wracając do początku, można by wręcz powiedzieć, że współcześnie świadomość metodologiczna antropologów i socjologów jakościowych nie pozwala im nie doceniać roli badacza (jako

${ }^{5} \mathrm{Na}$ zarzuty tego typu, stale pojawiające się w dyskusji naukowej, chciałoby się odpowiedzieć, że badacz (każdy badacz społeczny i humanistyczny) musi zdawać sobie sprawę z tego, iż ostatecznie zawsze dochodzi właśnie do wywoływania zmiany — poprzez udział w kształtowaniu dyskursu, wyznaczanie kierunków rozwoju idei, teorii, pojęć za sprawą światopoglądów, ideologii, „podejść do życia". U podstaw każdej nauki leżą jakieś wartości i jakaś filozofia. Ujawniać owe filozoficzne fundamenty teorii i badań nakazał już zwrot humanistyczny w naukach społecznych. Zwrot postmodernistyczny ujawnił natomiast pluralizm hybrydowych, patchworkowych, „przygodnych” filozofii, na których ufundowana jest ponowoczesna nauka. Koronny argument wysuwany przeciwko badaniom uczestniczącym (takim jak klasyczna etnografia, obserwacja uczestnicząca, antropologia zaangażowana czy autoetnografia właśnie) o wpływie na badaną rzeczywistość i powodowaniu zmian, a więc „zanieszczyczaniu” przedmiotu badań przez obecność badacza, w tym kontekście traci swoją siłę. 
konkretnej osoby) w procesie badawczym. I dlatego autoetnografia, jako studium „ludzkich narzędzi badawczych” - czy też „badaczy-osób” — stała się dziś niejako standardem w badaniach jakościowych.

Anna Wyka (1993), która w modelu badań poprzez wspólne doświadczenie przeniosła na grunt polskiej socjologii jakościowej ideę podejścia „klinicznego” w autorefleksji badawczej (Berg, Smith 1988), mówi o trzech kluczowych kwestiach je kształtujących. Po pierwsze, jest to założenie o podmiotowości wszystkich uczestników aktu badawczego (czyli i badanych, i badacza). Dalej mamy dyrektywy metodologiczne, takie jak: konieczność d oświ ad cz a n i a badanej rzeczywistości, rozumiana jako radykalny postulat, „który idzie znacznie dalej niż znane z tradycyjnej socjologii «humanistyczej» postulaty «uczestnictwa» badacza" (Wyka 1993, s. 55); oraz — sedno owego doświadczania - zachęta do tworzenia wspólnoty opartej na wymianie perspektyw i podzielaniu świata przez badanych i badaczy. $Z$ tych wytycznych rodzą się dalsze obwarowania modelu badań poprzez wspólne doświadczenie, a są to - jak za „klinicystami” społecznymi pisze Wyka - elastyczne podążani e za empirią, tak by na każdym etapie badawczym nastąpiła ugruntowana interpretacja (postulat zbieżny $\mathrm{z}$ metodologią teorii ugruntowanej); a także to, co z perspektywy metodyki pracy wydaje się najważniejsze, czyli wymóg samobadania, samokontroli i gromadzenia samowied zy przez badacza. W wyniku tej pracy - „klinicznego” przyglądania się sobie - badacz staje się narzędziem badawczym. Owa praca nad badaczem-narzędziem nie jest jednak celem samym w sobie, ale ma służyć sprawniejszemu, bardziej wiarygodnemu, "gęstszemu” opisywaniu światów społecznych. Spojrzenie Wyki jest tu bliskie rozważaniom Ruth Behar (1996, s. 14), która twierdzi, że w żaden sposób nie broni się autor pojawiający się w tekście jedynie jako ornament, „pokazanie siebie [...] musi zabrać nas w takie rejony, do których w inny sposób nigdy byśmy nie dotarli". Pod względem metod pracy zaś podejście „kliniczne” znajduje kontynuację i rozwinięcie w autoetnografii analitycznej, która zakłada, że badacz jest nastawiony na „analizowanie swoich działań i spostrzeżeń $\mathrm{w}$ odniesieniu do i w powiązaniu $z$ działaniami i spostrzeżeniami innych" (Anderson 2014, s. 153), przy czym kieruje się takimi zasadami jak: „(1) pełne uczestnictwo w badanym środowisku [...], (2) refleksyjność analityczna, (3) obecność własnego Ja badacza w narracji, (4) dialog z innymi informatorami niż Ja badacza, (5) zaangażowanie w analizę teoretyczną" (Anderson 2014, s. 149; por. Kacperczyk 2014).

Potencjał powyższych podejść — „klinicznego” i analitycznego - ujawnia się zwłaszcza podczas badania społecznych światów emocji, które stanowiły przedmiot moich studiów ${ }^{6}$. Podmiotowe, osobowe, sprawcze zaagażowanie ba-

${ }^{6}$ Opisana dalej metoda autoetnograficzna powstała $\mathrm{w}$ toku badań przeprowadzonych przeze mnie na potrzeby pracy doktorskiej pt. „Emocje w interakcjach intymnych i towarzyskich. Badania eksploracyjne praktyk flirtu i uwodzenia w sanatoriach i na imprezach klubowych". Praca została 
dacza w proces badania emocji uczyniłam kluczem metodologicznym. Bez próby wzbudzenia i odczucia emocji budujących życie intymno-towarzyskie, bez wykonania pracy emocjami, a następnie bez próby ich udyskursowienia w opisie niemożliwe wydaje się zrozumienie sensu i znaczenia sfery emocji, która interesuje badacza o nastawieniu fenomenologicznym i empirycznym. Z kolei zebranie tych doświadczeń i ich krytyczną analizę umożliwia zastosowanie autoetnografii (czy też, w słowniku Wyki, gromadzenie samowiedzy przy użyciu intelektualnych i pozaintelektualnych narzędzi samokontroli). Podmiotowość, „doświadczeniowość” i wspólnotowość, czyli przyjęte założenia o pewnej postawie badawczej, implikują więc zastosowanie metody autoetnografii „klinicznej” czy analitycznej. Szczególnie cenne, dostosowane do przedmiotu badań, wydaje się „[...] uwzględnienie w takiej «klinicznej» analizie tych wymiarów podmiotowości badającego, które na ogół się lekceważy lub całkowicie pomija, np. emocjonalnej strony procesu badawczego, w tym dynamiki emocjonalności jako istotnego składnika tego procesu; dynamiki poznawczej badacza (w tym dynamiki procesów in telektualny ch); roli pozaintelektualnych źródeł poznania w procesie badawczym, w tym roli jego zmysłów, czy ogólniej - cielesności bądź organiczności (jako przedmiotu samopoznania i samokontroli badawczej)" (Wyka 1993, s. 81-82; podkr. A.W.).

W wymiarze praktycznym „kliniczna” autoanaliza była w moich badaniach usystematyzowanym procesem, obejmującym indywidualne autorefleksje (zapisywane $\mathrm{w}$ formie kart obserwacji badacza) oraz grupowe superwizje (obserwacje prowadzone były zespołowo; zob. Kalinowska 2015) ${ }^{7}$. Ponadto przez cały czas pisałam osobisty pamiętnik, w którym pojawiają się ślady emocji związanych $z$ pracą terenową, intuicje badawcze oraz tropy teoretyczne. Staraliśmy się, wraz z innymi badaczami zaangażowanymi w obserwacje, kłaść równie duży nacisk na rozumowe drogi doświadczania i systematyzowania wiedzy o świecie życia oraz na korzystanie $z$ takich źródeł poznania jak własna cielesność i zmysłowość, fizyczne i intelektualne odczuwanie emocji, wyobraźnia podsuwająca różne metaforyki opisu obserwowanych zjawisk, intuicyjne schematy myślenia potocznego. W notatkach i dokumentacji $z$ etapu prac terenowych dużo miejsca poświęciliśmy zwłaszcza wyjaśnianiu procesów tworzenia i weryfikacji przedsądów dotyczących życia intymno-towarzyskiego. Ćwicząc niestandardowe (usytuowane poza systemem logiki naukowej) narzędzia poznania i samo-

napisama pod kierunkiem prof. Barbary Fatygi i obroniona w Instytucie Stosowanych Nauk Społecznych UW.

7 Stosowana podczas obserwacji triangulacja postaw badacza jako zaangażowanego „bawiącego-się-uczestnika” i zamiennie zdystansowanego „obserwatora-cienia” była bezpośrednio zainspirowana metaforą Marsjaniana i Konwertyty opisaną w podręczniku metodologicznym Analiza układów społecznych (Lofland i in. 2009), którego współautorem jest Leon Anderson (2014), jeden z głównych propagatorów podejścia analitycznego w autoetnografii. 
kontroli, „badacze jako narzędzia badawcze” zostali — jeśli można tak powiedzieć - sprofilowani do badania problematyki emocji podlegającej w przeważającej mierze sferze przedrefleksyjnej, procesom myślenia szybkiego (Kahneman 2012). Chodziło o to, by zbliżyć się jak najbardziej do przedmiotu badań, bezpośrednio dotknąć świata życia, ale mieć (móc stworzyć) narzędzia do zakomunikowania tych dotknięć w sposób zrozumiały dla wspólnoty naukowej. I choć „[...] owa bliskość, podręczność niemal, przedmiotu poznania naukowego rodzi wątpliwości natury metodologicznej dotyczące możliwości obiektywnego oglądu tego, co jest częścią doświadczenia biograficznego podmiotu poznającego" (Badura 2015, s. 45), uznałam za krok konieczny skierowanie szczególnej uwagi na celebrowanie „owej bliskości” badacza z badanym światem, tak aby metodologia badania współgrała z koncepcją teoretyczną. Chodziło o to, żeby nie rezygnować z tego wszystkiego, co wiemy i/lub przypuszczamy o miłości, flirtach i emocjach, będąc sobą — zwykłym mieszkańcem codzienności. Pragnę zaznaczyć, że był to krok w stronę poszerzenia pola metod badawczych o pozadyskursywne formy doświadczania świata życia, co nie oznacza — a przynajmniej taką mam nadzieję - że zastosowana metodologia wzięła rozbrat ze „zdyscyplinowanym sposobem posługiwania się rozumem, który chroni przez popełnianiem błędów" (Badura 2015, s. 20).

\section{„BADACZ PODATNY NA ZRANIENIE”}

Myślenie o badaczu jako o narzędziu niesie ze sobą poważne ryzyko. Badacz sprowadzony do roli li tylko narzędzia może, wbrew intencjom, zostać potraktowany przedmiotowo (użytkowo) - jako samoświadomy, doskonale przygotowany i ciągle „ulepszający się” specjalista, który jest, co prawda, sam dla siebie podmiotem krytycznej analizy, ale tylko w odniesieniu do swojej roli zawodowej, w kontekście „bycia badaczem”, w celu wzmocnienia metodologii. Tymczasem badacze terenowi, prowadzący niekiedy bardzo obciążające emocjonalnie badania, angażujący swoją osobę w dotarcie do trudnych tematów, sygnalizują, że ważne są nie tylko efekty ich pracy naukowej i kompetencje uwiarygodniające owe efekty, ale także dostrzeżenie procesów życiowych i osobistych doświadczeń, które były ich udziałem $\mathrm{w}$ związku z badaniami uczestniczącymi (Hammersley, Atkinson 2000; Kleszcz 2004; Oliwińska 2008). Jak podkreśla Wyka (1993, s. 82): „różne «ja» badacza: jego emocjonalność, cielesność, obok możliwości intelektualnych, można rozumieć nie tylko jako pewne wymiary (a dokładniej - metawymiary) jego badawczego funkcjonowania, czyli jako cechy strukturalne jego podmiotowości, ale także najzupełniej dosłownie. To znaczy jako staw a n i e si ę «kimś innym» w trakcie badań, lub po ich zakończeniu, gdy przeszliśmy przez różnorakie doświadczenia, które zmieniły nas samych”. Dlatego koncepcję „badacza jako narzędzia” proponuję uzupełnić (albo lepiej — zrównoważyć) koncepcją „badacza podatnego na zranienie" (Behar 1996; Kuligowski 2007). 
Vulnerable observer, czyli badacz podatny na zranienie lub - zależnie od tłumaczenia - po prostu wrażliwy/uwrażliwiony badacz, to ktoś, kogo ujmujemy nie tylko w kontekście jego predyspozycji do współdoświadczania i czułości jako narzędzia badawczego. Taka perspektywa stawiałaby go bowiem na pozycji drugorzędnej, jego podmiotowość musiałaby być podporządkowana temu, jak rozumują, jak odczuwają, jak funkcjonują „właściwi” bohaterowie antropologicznej opowieści - badane społeczności, światy, instytucje czy kultury. To z kolei oddala od owej, wspomnianej przez Ossowskiego (2001, s. 13-14), uprzywilejowanej pozycji introspekcji, wynikającej z bezpośredniego dostępu do „rzeczy samych w sobie”. Koncepcja badacza podatnego na zranienie $\mathrm{w}$ innym miejscu stawia akcent: na pierwszy plan wysuwa się tu doświadczenie biograficzne badającego. To właśnie doświadczenie - zdarzenie, proces, spotkanie - odczuwane jako przemiana osobista, a jednocześnie jako doświadczenie kulturowe, „stanowi «esencję» autoetnografii” (Kossakowski 2014, s. 99) i jej przedmiot. Różnica polega na przesunięciu punktu ciężkości. Przyglądamy się temu, jak badana rzeczywistość odkształca świat przeżywany badacza. Co go dotyka, zmienia? Co przekierowuje jego biografię na inne tory? W jakich sytuacjach i w zetknięciu $z$ jakimi ideami/prakty$\mathrm{kami} /$ zdarzeniami badacz podatny jest na zranienia oraz kiedy zyskuje poczucie oczywistości swojego świata? Mniej znaczące wydaje się patrzenie z perspektywy badanych, zobaczenie ich świata „od środka”, „wchodzenie w obce buty”, postawienie się $w$ ich sytuacji, utożsamienie się z Innym, empatyczne wczucie się $\mathrm{w}$ cudze życie. Badany świat zostaje wyjaśniony i zrozumiany $\mathrm{w}$ przeżyciu i ustosunkowaniu go do osobistego doświadczenia badacza, a nie poprzez eksperymentalną próbę doświadczenia bycia badanym. To zdejmuje $z$ badającego duży ciężar ciągłego udowadniania, że „naprawdę” żył, odczuwał, myślał jak Inni (co zawsze będzie antropologiczną iluzją ${ }^{8}$, gdyż naprawdę żyjemy, odczuwamy, myślimy tylko jak my sami). Ponadto roszerza definicję badań uczestniczących/„doświadczeniowych” poza to, co eksponuje wyłącznie perspektywę badanych. Owa „podatność na zranienia” może się więc wydawać niewielką ceną za uwolnienie badacza od konfliktu pełnionych przez niego ról społecznych i zawodowych. To miałam na myśli, pisząc o konieczności zrównoważenia koncepcji „badacza jako narzędzia”.

${ }^{8}$ Mój zwrot ku autoetnografii wynika w dużej mierze z krytycznej analizy własnych doświadczeń badania młodzieży, opartych na tej właśnie iluzji zobaczenia cudzego świata „od środka” (zob. Kalinowska 2012) oraz z rozmów z Iwoną Oliwińską o możliwościach (i konieczności) terapeutyzowania trudnych doświadczeń terenowych. Na kształtowanie mojego stanowiska wobec umieszczenia badacza w obrębie metody badawczej duży wpływ miały także badania Barbary Fatygi (1999) dotyczące liderów grup młodzieżowych o różnym profilu ideowym. Autorka zmodyfikowała w tych badaniach metodę wywiadu narracyjnego, dopuszczając do głosu badacza, który był nie tylko słuchaczem opowieści (jak jest wskazane w tego typu badaniach), ale zyskał sposobność wypowiedzenia swojego stanowiska w kwestiach omawianych podczas wywiadu (ostatni etap wychodzenia z sytuacji wywiadu umożliwiał dyskusję światopoglądową między badaczem a badanym). 
Jak w zespołowej praktyce badawczej realizowaliśmy postawę badacza podatnego na zranienie? Po pierwsze, nie staraliśmy się zawieszać naszych przedsądów, wręcz przeciwnie - pielęgnowaliśmy je, rozpracowywaliśmy, analizowaliśmy, a w wyniku zetknięcia z terenem niekiedy je umacnialiśmy, a niekiedy modyfikowaliśmy. Rzetelnie przy tym zdawaliśmy sprawę $z$ tych transformacji w notatkach terenowych.

Po drugie, dbaliśmy o dokładne oznaczanie naszych osobistych granic zaangażowania $\mathrm{w}$ intymno-towarzyskie relacje nawiązywane podczas pobytów w terenie. Chodziło o odnotowywanie takich momentów, w których przestawaliśmy czuć się pewnie i/lub bezpiecznie w interakcjach, gdy jakieś zachowania wydawały nam się zbyt śmiałe lub przeciwnie - śmiesznie zachowawcze. Kluczowe były te sytuacje, w których „nie poznawaliśmy samych siebie” albo z których chcieliśmy jak najszybciej uciec; reakcje, o które siebie samych nie podejrzewaliśmy albo $\mathrm{z}$ którymi usilnie walczyliśmy. Praca $\mathrm{w}$ terenie, a w niektórych przypadkach już dyskusje zespołowe wymagały od nas wyjścia ze swojej strefy komfortu. Ta koncepcja, obecnie popularna w psychologii (zob. choćby White 2008), zaleca porzucenie tego, co oswojone, sprawdzone, bezpieczne, a wystawienie się na działanie nieznanego, innego, powodującego potencjalnie pozytywną, cenną i rozwijającą zmianę. Nam chodziło o namierzenie punktów zapalnych - miejsc, w których zetknięcie z czymś nie-swoim dotykało badacza, naruszało jego granice, a poprzez to uwidoczniało inność badanego świata od świata badacza. Epistemologiczne źródło tych zabiegów zawiera się w słowach, którymi Tomasz Rakowski (2009, s. 30) referuje podejście Merleau-Ponty'ego: „To napotkanie innego człowieka zawsze wymusza więc pewną reorganizację świata, wymusza uwagę i nowy sposób bycia wobec jej przedmiotów - wymusza przesunięcie całego pola". W tym sensie spotkanie, pielęgnowanie „swojskości”, konfrontowanie jej z ,innością” i kontrolowanie owych konfrontacji oraz powstałych przy nich „zranień” (dotknięć, odkształceń) stało się strategią poznawczą.

Po trzecie, koncepcja vulnerable observer jest skoncentrowana wokół ciągłości i zmiany biografii badacza. Duże znaczenie ma przeszłość, wspomnienia, introspekcja, a także śledzenie aktualnie toczących się procesów przekształcania postaw, poglądów, preferencji, typowych dla danego badacza zachowań, gestów, praktyk. Wyczuleni na obserwację tego typu zmian, w kartach obserwacji badaczy prowadziliśmy coś w stylu osobistych rejestrów "odkształceń" oczywistości, swojskości i własnych biografii. Owe rejestry były ważne $z$ dwóch powodów. Pozwalały badaczom uporać się ze „zranieniami”, wytłumaczyć i kontrolować wpływ udziału w tak mocno angażujących badaniach. Były więc narzędziem terapeutycznym. Poza tym stanowiły materiał analityczny. Odnotowane przez badaczy „odkształcenia” rozpatrywałam mając na uwadze, że różni badacze w różnym stopniu są „podatni na zranienia”. Rejestry pomogły mi w ustaleniu siły i natężenia emocji; w opisie atmosfery/klimatu badanego świata; oraz w określeniu stopnia podatności praktyk kulturowych 
na replikację - dyskursywną bądź pozadyskursywną. Innymi słowy, rejestrowanie sytuacji „odkształcania” badaczy, pozwalało dostrzec, co może stanowić o spójności lub sprzecznościach w postrzeganiu przedmiotu badania, co w badanych światach ma potencjał ich symbolicznego organizowania, co natomiast jest relacyjne i negocjowalne.

\section{KOMUNIKOWANIE AUTOETNOGRAFII - WYWOŁYWANIE BEZ NAWOŁYWANIA}

Antropologia, którą pokazuje badacz podatny na zranienie, winna być jak chce Behar - „antropologią, która łamie serce” (anthropology that breaks your heart), czyli ma docierać do emocji, przywoływać wspomnienia, ale też pobudzać do przemiany. To przekaz, który przeżywa się nie tylko intelektualnie. Autoetnografom ewokatywnym ${ }^{9}$ (czy też sugestywnym; zob. Kossakowski 2014) - do których grona można zaliczyć, oprócz Ruth Behar, między innymi Carolyn Ellis, Stacy Holman Jones, Artura Bochnera (zob. Holman Jones 2009; Kafar 2009; 2014; Kacperczyk 2014) — chodzi o pewną retorykę i stylistykę wypowiedzi etnograficznej, o taki sposób powoływania narracji (w tekście bądź performansie), który prowadzi do „wytworzenia namacalnego, emocjonalnego doświadczenia" (Holman Jones 2009, s. 181), mającego za zadanie „kierowanie ludzi ku zrozumieniu świata” (Bielecka-Prus 2012, s. 207). Koncepcja „antropologii łamiącej serce”, oprócz zwrotu ku temu, co osobiste najgłębiej ukryte, a zarazem najbardziej dostępne badaczowi - mieści także pewne wyzwanie interakcyjne, komunikacyjne. Pisząc o „antropologii, która łamie serce” i „robiąc” taką antropologię, Ruth Behar chce ośmielić badaczy do równie wrażliwej odpowiedzi na lekturę, do uprawiania antropologii, która ma dla nich realne znaczenie; jej intencją jest przekonać środowisko naukowe do zajmowania się sprawami bliskimi, ważnymi tu i teraz; do zabierania głosu w kwestiach społecznych, antropologicznych i filozoficznych; do odsłaniania świata emocji i przeżyć; do zatrzymania się na swoim partykularnym doświadczeniu, bez obaw o bycie posądzonym o subiektywizm i ekshibicjonizm. Behar (1996, s. 32) pisze: „Być podatnym na zranienie to, w skrócie, zatrzymać się tu [w swoim miejscu, na sobie - K.K.]. Krytycy mogą wymawiać temu podejściu, że jest formą "solipsyzmu», ale wielu z nas zamierza dalej nosić swoje serce na dłoni”. A więc snując szczere, autobiograficzne opowieści, tworzyć ujście dla

\footnotetext{
${ }^{9}$ Autoetnografia ewokatywna/sugestywna, w odróżnieniu od autoetnografii analitycznej, nie akcentuje systematycznego, proceduralnego, ujętego w uogólnioną metodę śledzenia i analizowania doświadczenia badacza, wpisanego w klasyczną metodologię rozwijaną na gruncie symbolicznego interakcjonizmu i socjologii interpretatywnej. Koncentruje się w zamian na postulacie zmiany paradygmatu w naukach jakościowych. Ta zmiana ma na celu przede wszystkim uznanie polityczności i zaangażowania badań społecznych za ich największe wyzwanie, uzasadnienie i legitymizację. Ów cel osiągnąć można najpełniej (wyłącznie?) dzięki snuciu osobistych, sugestywnych opowieści (zob. Kacperczyk 2014; Anderson 2014; Holman Jones 2009; Kafar 2009; Denzin 1997).
} 
„wyjątkowo wstydliwej i sprywatyzowanej wiedzy profesjonalnej” antropologa (Rakowski 2009, s. 41).

Jeśli „ewokatywny” to według słownikowej definicji „wywołujący uczucia, wspomnienia; przywołujący jakąś wizję" (zob. SJP), to uważam, że taki sugestywny, plastyczny, „uzmysłowiony” język jest naukom społecznym potrzebny. Skoro doświadczenie etnograficzne i badany temat są dostępne nie tylko intelektualnie, dobrze móc pokazać to w tekście. Autoetnografia ewokatywna — jako całościowy projekt metodologiczny, teoretyczny i polityczny — idzie jednak dalej, ku zmianie paradygmatu na zaangażowany w planowe, zamierzone, świadome kształtowanie praktyk kulturowych i modelowanie wrażliwości (Holman Jones 2009). To nurt, który nie tylko liczy na wywołanie zmian w obszarze metodologii nauk społecznych, ale także stawia sobie za cel zmienianie życia zarówno piszącego, jak i czytelnika oraz, ogólnie mówiąc, świadomości społecznej. Choć nauki o człowieku zawsze są w mniej lub bardziej uwikłane i zaangażowane w kształtowanie kultury, to jednak nie jestem przekonana, czy zawsze powinny bezpośrednio i celowo nawoływać do zmiany i wskazywać obszar zmian (tzn. czy dążenie do zmiany powinno być wpisane w projekt badawczy) ${ }^{10}$. Bardziej etyczne wydaje się podejście socjologii do kreowania zmian społecznych, jak choćby w koncepcji interwencji socjologicznej Alaina Touraine'a (2010), gdy badacz kieruje się w stronę problemu, który określa (konstruuje) grupa bądź ruch społeczny przy pomocy socjologa $\mathrm{w}$ procesie konsultacji kierującego refleksyjnością grupową. Bada przy tym wpływ samoświadomości ludzi na rozwiązywanie problemu i zmianę społeczną oraz daje badanym informację zwrotną. W „programowym” zaangażowaniu antropologii, polegającym na konstruowaniu problemu i uwarażliwianiu nań, widzę jednak dość niejednoznaczną (kolonizująca) praktykę - polityczne ma być samo działanie badawcze, o kierunku zmiany i zaangażowania decyduje badacz i dyskurs wewnątrz dyscypliny. Dlatego wolę zatrzymać się na użyciu autoetnografii w stricte metodologicznym kontekście i traktować ją jak technikę otrzymywania danych i metodę oraz strategię badawczą (o możliwych sposobach traktowania autoetnografii zob. Kacperczyk 2014). Największą zaletę sięgania po autoetnografię widzę nie w sprawczej mocy osobistych świadectw i sugestywnych narracji ${ }^{11}$, ale $\mathrm{w}$ „o d m y ka ni u” $\mathrm{w}$ trakcie całego procesu badawczego tych kanałów poznania i pokładów wiedzy, które nie są tradycyjnie wpisane w postawę naukową, a mają dużą szan-

\footnotetext{
${ }^{10}$ Mam na myśli badania akademickie i podstawowe. W przypadku badań stosowanych, których rolą jest rozwiązywanie problemów społecznych, do których „przychodzi się z pytaniami” (Mokrzycki 2007), sprawa wygląda inaczej. W badania społeczne i rynkowe mające charakter usługowy wpisane jest zaangażowanie i projektowanie zmian.

${ }^{11}$ Historia myśli społecznej i humanistycznej pokazuje, że ogromną siłę oddziaływania i zmieniania ludzkich żyć i kształtu kultur mają także teksty całkowicie teoretyczne i odrealnione, nawet te napisane topornym, wydawać by się mogło, niesugestywnym językiem, łamiącym raczej nie serca, lecz języki i umysły.
} 
sę pobudzać wyobraźnię socjologiczną badacza. Pisanie „antropologii, która łamie serca” rozumiem raczej jako (1) umieszczanie w tekście śladów „autonomicznej obcości" badacza, która uwidocznia się w spotkaniu z Innym oraz (2) poszukiwanie w możliwościach językowych „pretekstowego żywiołu dyscypliny" (zob. Rakowski 2009, s. 42), co jest pewnym sposobem na kontrolę doświadczenia etnograficznego.

Postulat pisania „antropologii, która łamie serce” (metafora podszyta jest tragizmem, trzeba przyznać), realizuję przede wszystkim sięgając $\mathrm{w}$ opisach do osobistych przeżyć i języka własnych doświadczeń w polu badawczym. Nie snuję jednak narracji wokół jakiegoś szczególnego osobistego doświadczenia granicznego, czy trajektoryjnego, jak często dzieje się w przypadku tekstów w nurcie autoetnografii ewokatywnej. Być może ze względu na tematykę moich badań nie jestem skłonna obstawać przy metaforze „antropologii łamiącej serca”. Podobnie jak pisałam o badaczu podatnym nie wyłącznie na zranienia, ale też na wszelkie odkształcenia, dotknięcia i poruszenia (niekoniecznie związane $z$ trudnym, traumatycznym, bolesnym przeżyciem), tak też wolę mówić o antropologii, która nie musi „łamać serca”, wystarczy, że je nieco „połechta”.

\section{NARZEDZIA AUTOETNOGRAFII}

Refleksje autoetnograficzne i odwołania do autorskiego Ja w praktykach badawczych wciąż mają najczęściej postać nieuporządkowanych wzmianek na marginesie tekstu. Obecność refleksji autoetnograficznych na gruncie nauk społecznych nie zawsze wiąże się z rozwojem autoetnografii jako krytycznej metody badawczej. „Kliniczne” podejście do samoobserwacji badacza i analityczny wariant metody zobowiązują do uporządkowania metodyki pracy. Poniższe zestawienie technik i narzędzi badawczych pokazuje, $w$ jaki sposób rejestrowana i opracowywana była autoetnografia $\mathrm{w}$ prowadzonym przeze mnie projekcie badawczym.

Starałam się pokazać, że autoetnografię potraktowałam jako kompleksową metodę badawczą, która miała udział w konceptualizowaniu warstwy teoretycznej, rozwiązywaniu kwestii metodologicznych, a także w pracy nad osobistym obszarem biografii badaczy. Każda $z$ opisanych form pracy doświadczeniami wewnętrznymi miała $\mathrm{w}$ procesie badawczym inne znaczenie. Pierwsze impulsy interpretacyjne, a także język opisu badanego świata, pochodziły zazwyczaj $z$ obserwacji pozyskanych $\mathrm{w}$ wyniku introspekcji nazwanej przeze mnie teoretyczną. Praktyki badawcze były „ciosane” w toku autorefleksji metodologicznych. Swoistym wentylem bezpieczeństwa dla badaczy zaangażowanych $\mathrm{w}$ projekt było przeprowadzenie przygotowawczej, retrospektywnej autoanalizy introspekcyjnej. Mam wrażenie, że w tym połączeniu technik autoetnograficznych udało się znaleźć miejsce i na specyficznie rozumianą autoetnografię o charakterze ewokatywnym (wzbudzającym), i na praktykowanie autografii analitycznej/,klinicznej”; na pisanie i na działanie; na przy- 
Techniki i narzędzia pracy (opracowanie własne)

\begin{tabular}{|c|c|c|}
\hline $\begin{array}{c}\text { Techniki } \\
\text { autoetnograficzne }\end{array}$ & Typ i przedmiot autorefleksji & $\begin{array}{l}\text { Narzędzia } \\
\text { badawcze }\end{array}$ \\
\hline $\begin{array}{l}\text { Autoanaliza intro- } \\
\text { spekcyjna } \\
\text { (ten typ autoob- } \\
\text { serwacji nie stano- } \\
\text { wił materiału źró- } \\
\text { dłowego do analiz } \\
\text { teoretycznych, ale } \\
\text { wspomagał two- } \\
\text { rzenie kluczy in- } \\
\text { terpretacji) }\end{array}$ & $\begin{array}{l}\text { Konfrontacja z przedsądami, wspomnieniami i doświad- } \\
\text { czeniami związanymi z obszarem badań; przepracowanie } \\
\text { swojego stosunku do terenu i oczekiwań względem ba- } \\
\text { dań; uporanie się z „,nalotem psychologicznym”, który } \\
\text { mógłby zmącić odbiór doświadczeń badawczych; wyło- } \\
\text { nienie osądów (sfery oceny) podczas analizy osobistych } \\
\text { doświadczeń. Swoiste „oczyszczenie pola”, ponieważ so- } \\
\text { cjolog „[...] musi być w pełni świadom różnicy między } \\
\text { tym, co do czego ma pewność, że doświadczył tego świa- } \\
\text { domie w czasie, gdy był czynny, a wszystkim, co może } \\
\text { mu się przytrafić, kiedy będzie próbował teraz zrozumieć } \\
\text { swoją przeszłą działalność” (Znaniecki 2009, s. 190). }\end{array}$ & $\begin{array}{l}\text { karty obserwacji } \\
\text { badaczy } \\
\text { osobiste pamiętni- } \\
\text { ki }\end{array}$ \\
\hline $\begin{array}{l}\text { Introspekcja teore- } \\
\text { tyczna } \\
\text { (równorzędne - } \\
\text { obok obserwacji } \\
\text { etnograficznych } \\
\text { i treści wywiadów } \\
\text { — źródło materia- } \\
\text { łu do analizy) }\end{array}$ & $\begin{array}{l}\text { Poddanie refleksji - „pierwotnej formie czynności teore- } \\
\text { tycznej” (Znaniecki 2009, s. 189) - własnych zachowań, } \\
\text { przemyśleń, zaskoczeń i odczuć, które fa k ty cz n i e } \\
\text { pojawiają się w toku badań (są wywołane przez do- } \\
\text { świadczenie spotkania, terenu, tematu) i mogą zostać po- } \\
\text { traktowane jako doświadczalne fakty (n i e s ą d o i n ter - } \\
\text { pre to w a ne). Są to „oryginalne doświadczenia kulturo- } \\
\text { we w takiej postaci, w jakiej rzeczywiście występują w ży- } \\
\text { ciu” (Znaniecki 2009, s. 193), co skłania nas - badaczy } \\
\text { - do tego, aby „[...] skierować naszą uwagę na poszcze- } \\
\text { gólne wartości, z którymi mieliśmy lub mamy do czynie- } \\
\text { nia, i na sposób, w jaki mieliśmy lub mamy tendencję } \\
\text { do łączenia oraz modyfikowania tych wartości” (Znaniec- } \\
\text { ki 2009, s. 188). W ten oto sposób socjolog rozumieją- } \\
\text { cy „spożytkowuje dane doświadczenia jako materiał do } \\
\text { konstrukcji teoretycznej, modyfikując oraz reorganizując } \\
\text { je dla własnych celów” (Znaniecki } 2009 \text {, s. 189). } \\
\text { Czynność autorefleksji obejmująca całość doświadczeń } \\
\text { badacza, które korespondują w jakiś sposób z prowa- } \\
\text { dzonym badaniem. Etnografia własnej osoby zarówno } \\
\text { w kontekście zderzenia z terenem, jak i w obliczu in- } \\
\text { nych sytuacji z życia codziennego i intelektualnego (np. } \\
\text { wrażenia powstałe podczas lektur, odbioru tekstów kul- } \\
\text { tury, obserwacje potoczne nieobjęte schematem badaw- } \\
\text { czym itd.). Według wskazówki sformułowanej przez } \\
\text { Millsa w eseju O rzemiośle intelektualnym (2007, s. 304): } \\
\text { „Jeśli kiedykolwiek zrobi na tobie silne wrażenie jakieś } \\
\text { wydarzenie lub myśl, musisz spróbować nie pozwolić } \\
\text { im przemknać przez twój umysł, lecz ująć je w słowach } \\
\text { w swoim katalogu i w ten sposób wydobyć ich konse- } \\
\text { kwencje, unaoczniając samemu sobie albo głupotę tych } \\
\text { odczuć czy myśli, albo też to, jak można je wyrazić w bar- } \\
\text { dziej produktywnej formie. [...] Prowadzenie katalogu } \\
\text { oznacza aktywne kontrolowanie doświadczenia”. }\end{array}$ & $\begin{array}{l}\text { rejestr „zra- } \\
\text { nień”, „dotknięć” } \\
\text { i „odkształceń” } \\
\text { w dzienniku bada- } \\
\text { cza } \\
\text { katalog teoretycz- } \\
\text { ny w dzienniku } \\
\text { badacza }\end{array}$ \\
\hline
\end{tabular}




\begin{tabular}{|c|c|c|}
\hline $\begin{array}{c}\text { Techniki } \\
\text { autoetnograficzne }\end{array}$ & Typ i przedmiot autorefleksji & $\begin{array}{l}\text { Narzędzia } \\
\text { badawcze }\end{array}$ \\
\hline $\begin{array}{l}\text { Autorefleksja me- } \\
\text { todologiczna } \\
\text { (ten typ autoob- } \\
\text { serwacji był pod- } \\
\text { stawą dopracowy- } \\
\text { wania metodologii } \\
\text { badań; był tak- } \\
\text { że formą kształ- } \\
\text { cenia i działania } \\
\text { terapeutycznego } \\
\text { badaczy zaangażo- } \\
\text { wanych w projekt) }\end{array}$ & $\begin{array}{l}\text { Gromadzenie samowiedzy o sobie jako narzędziu badaw- } \\
\text { czym, weryfikacja własnego przygotowania do pracy w te- } \\
\text { renie klubowym/sanatoryjnym, analiza swoich mocnych } \\
\text { i słabych stron jako badacza społecznego, rozwijanie róż- } \\
\text { norakich kanałów poznania (zwłaszcza pozaintelektual- } \\
\text { nych), jakimi dysponuje badacz (Wyka 1993). } \\
\text { Przepracowywanie problemów z terenu, zrzucenie baga- } \\
\text { żu emocjonalnego. } \\
\text { Porządkowanie doświadczeń, ocena charakteru swoich } \\
\text { obserwacji (określanie, czy dane obserwacje mają cha- } \\
\text { rakter psychologicznej autoanalizy introspekcyjnej, czy } \\
\text { introspekcji teoretycznej dotykającej faktów społecznych } \\
\text { i kulturowych) - „rozróżnienie tak ściśle, jak to tylko } \\
\text { możliwe między fakt a mi a wyja śn i e ni a mi” (Zna- } \\
\text { niecki 2009, s. 191) i ocena „modyfikującego wpływu in- } \\
\text { trospekcji” (Ossowski 2001, s. 28), by „w sposób odpo- } \\
\text { wiedzialny zdecydować, czy w sobie coś odkrywam, czy } \\
\text { tworzę” (Ossowski 2001, s. 24). }\end{array}$ & $\begin{array}{l}\text { metodologiczne } \\
\text { notatki w dzien- } \\
\text { niku badacza i na } \\
\text { kartach obserwacji } \\
\text { klubowej } \\
\text { rozmowy ze } \\
\text { współbadaczami } \\
\text { minifokusy } \\
\text { superwizje } \\
\text { konsultacje }\end{array}$ \\
\hline
\end{tabular}

bliżenie się do tematu i na oddalenie się, zdystansowanie od obszaru poszukiwań.

\section{AUTOETNOGRAFIA DOTKNIĘĆ, ZRANIEŃ I ODKSZTAŁCEŃ - PODSUMOWANIE}

Integracja dwóch projektów autoetnograficznych - „badacza jako narzędzia” i „badacza podatnego na zranienie” - wymaga powrotu do stanowiska teoretycznego i przypomnienia poczynionych założeń o naturze świata życia codziennego: „Otóż codzienne obchodzenie się z rzeczami przebiega w sposób płynny i niemal półautomatyczny. Człowiek przechodzi od jednej rzeczy do drugiej, podejmując i porzucając określone narzędzia. Dzieje się tak do mometu, kiedy pojawiają się zakłócenia w funkcjonowaniu któregoś z nich. To zakłócenie Heidegger opisuje za pomocą takich pojęć jak: nieużyteczność, nieporęczność, natrętność, bezradność, uporczywość" (Sobota 2012, s. 155). Zakłócenia są dlatego cenne, że uwidoczniają złożoność naszych światów społecznych, na co dzień pacyfikowaną i wypieraną przez modernistyczne narracje albo przeciwnie - przykrywaną przez ponowoczesne, gmatwające dyskursy. Proponowany przeze mnie sposób wykorzystania autoetnografii zakłada o p i syw a nie oczywistego, płynnego i półautomatycznego funkcjonowania świata życia codziennego poprzez "kliniczne" badanie zgrzytów, zaburzeń i niestyczności między „swoim” i „obcym” z punktu widzenia badacza. Wystawiając się na konsekwencje funkcjonowania w złożonym świecie emocji miłosnych, poddawanym rozmaitym strategiom oswajania, 
starałam się odkrywać zjawiska klubowych i sanatoryjnych emocji miłosnych takimi, jak są postrzegane, czyli jako: zaskakujące i oczywiste; komplikowane i upraszczane; eskalowane i redukowane. Nieużyteczność, nieporęczność, natrętność, bezradność, uporczywość - zakłócenia funkcjonowania oczywistości — ujawniają się wyraźnie w osobistym doświadczeniu badacza. Niekoniecznie i nie zawsze jest to doświadczenie negatywnie nacechowanego „zranienia”, ale raczej wszelkich „dotknięć”, „odkształcen”, „naruszeń strefy komfortu”.

\section{BIBLIOGRAFIA}

Anderson Leon, 2014 [2006], Autoetnografia analityczna, tłum. Maja Brzozowska-Brywczyńska, „Przegląd Socjologii Jakościowej”, t. 10, nr 3, s. 144-166.

Babbie Earl, 2004, Badania społeczne w praktyce, tłum. zbiorowe, Wydawnictwo Naukowe PWN, Warszawa.

Badura Grażyna, 2015, O obiektywności poznania socjologicznego raz jeszcze, Nomos, Kraków.

Behar Ruth, 1996, The Vulnerable Observer: Anthropology that Breaks Your Heart, Beacon Press, Boston.

Berg David N., Smith Kenwyn K., 1988, The Clinical Demands of Research Methods, w: David N. Berg, Kenwyn K. Smith (red.), The Self in Social Inquiry, Sage, Newbury Park.

Bielecka-Prus Joanna, 2012, Normana K. Denzina projekt etnografi i interpretacyjnej, w: Adam A. Szafrański (red.), Geertz. Dziedzictwo - interpretacje — dylematy, Wydawnictwo KUL, Lublin.

Blumer Herbert, 2007, Interakcjonizm symboliczny. Perspektywa i metoda, tłum. Grażyna Woroniecka, Nomos, Kraków.

Berger Peter L., Luckmann Thomas, 1983, Społeczne tworzenie rzeczywistości, tłum. Józef Niżnik, PIW, Warszawa.

Buchowski Michał, Kempny Marian (red.), 1999, Amerykańska antropologia postmodernistyczna, Instytut Kultury, Warszawa.

Burszta Wojciech J., 1993, Czy istnieje dekonstrukcja antropologiczna?, w: Aldona Jawłowska, Marian Kempny, Elżbieta Tarkowska (red.), Kulturowy wymiar przemian społecznych, IFiS PAN, Warszawa.

Clifford James, 2000, Kłopoty z kultura. Dwudziestowieczna etnografia, literatura $i$ sztuka, thum. Ewa Dżurak, Wydawnictwo KR, Warszawa.

Clifford James, Marcus George E. (red.), 1986, Writing Culture: The Poetics and Politics of Ethnography, University of California Press, Berkeley.

Denzin Norman K., 1997, Interpretive Ethnography: Ethnographic Practices for the $21^{\text {st }}$ Century, Sage, London.

Domańska Ewa, 2007, „Zwrot performatywny” we wspótczesnej humanistyce, „Teksty Drugie”, nr 5.

Durkheim Emil, 2000, Zasady metody socjologicznej, tłum. Jerzy Szacki, Wydawnictwo Naukowe PWN, Warszawa.

Fatyga Barbara, 1999, Dzicy z naszej ulicy. Antropologia kultury młodzieżowej, Ośrodek Badań Młodzieży, Warszawa.

Geertz Clifford, 2000, Dzieło i życie. Antropolog jako autor, tłum. Ewa Dżurak, Sławomir Sikora, Wydawnictwo KR, Warszawa.

Geertz Clifford, 2005a, Interpretacja kultury. Wybrane eseje, tłum. Maria M. Piechaczek, Wydawnictwo Uniwersytetu Jagiellońskiego, Kraków.

Geertz Clifford, 2005b, Wiedza lokalna. Dalsze eseje z zakresu antropologii interpretatywnej, tłum. Dorota Wolska, Wydawnictwo Uniwersytetu Jagiellońskiego, Kraków.

Hammersley Martyn, Atkinson Paul, 2000, Metody badań terenowych, tłum. Sławomir Dymczyk, Zysk i S-ka, Poznań. 
Hastrup Kirsten, 2008, Droga do antropologii. Między doświadczeniem a teoria, tłum. Ewa Klekot, Wydawnictwo Uniwersytetu Jagiellońskiego, Kraków.

Holman Jones Stacy, 2009, Autoetnografia. Polityka tego, co osobiste, tłum. Maja Brzozowska-Brywczyńska, w: Norman K. Denzin, Yvonna S. Lincoln (red.), Metody badań jakościowych, t. 2, Wydawnictwo Naukowe PWN, Warszawa.

Kacperczyk Anna, 2014, Autoetnografia — technika, metoda, nowy paradygmat? O metodologicznym statusie autoetnografii, „Przegląd Socjologii Jakościowej”, t. 10, nr 3, s. 32-74.

Kafar Marcin, 2009, O przełomie autoetnograficznym w humanistyce. W stronę nowego paradygmatu, w: Bożena Płonka-Syroka, Michał Skrzypek (red.), Doświadczanie choroby w perspektywie badań interdyscyplinarnych, Akademia Medyczna im. Piastów Śląskich, Wrocław.

Kafar Marcin, 2014, Wokót humanizacji nauki - znaki, tropy, konteksty, „Przegląd Socjologii Jakościowej”, t. 10, nr 3, s. 16-31.

Kahneman Daniel, 2012, Pułapki myślenia. O myśleniu szybkim i wolnym, tłum. Piotr Szymczak, Media Rodzina, Poznań.

Kalinowska Katarzyna, 2012, Interakcje pedagogiczne w szkole gimnazjalnej, „Przegląd Socjologii Jakościowej", t. 8, nr 3, s. 30-57.

Kalinowska Katarzyna, 2015, „Podryw kontrolowany” — praca zespołowa jako kluczowa reguta metodologiczna, w: Praktyki badawcze, Barbara Fatyga (red.), Zakład Metod Badania Kultury ISNS UW, Warszawa.

Kaufmann Jean-Claude, 2004, Ego. Socjologia jednostki. Inna wizja człowieka i konstrukcji podmiotu, tłum. Krzysztof Wakar, Oficyna Naukowa, Warszawa.

Kaufmann Jean-Claude, 2010, Wywiad rozumiejący, tłum. Alina Kapciak, Oficyna Naukowa, Warszawa.

Kleszcz Irena (Oliwińska Iwona), 2004, Wykorzystanie ukrytej obserwacji uczestniczącej w badaniu stylu życia szarej strefy, „Kultura i Społeczeństwo”, nr 2.

Kossakowski Radosław, 2014, Medytacja i futbolowa goraczka. O potencjale, ograniczeniach i domknięciach autoetnografii, „Przegląd Socjologii Jakościowej”, t. 10, nr 3, s. 96-122.

Kowalewski Jacek, Piasek Wojciech (red.), 2010, „Zwroty” badawcze w humanistyce. Konteksty poznawcze, kulturowe i społeczno-instytucjonalne, Instytut Filozofii Uniwersytetu Warmińsko-Mazurskiego, Olsztyn.

Kuligowski Waldemar, 2007, Antropologia wspótczesności. Wiele światów, jedno miejsce, Universitas, Kraków.

Kuligowski Waldemar, 2012, Różnicowanie nowoczesności. Nowa debata w antropologii społecznej, Wydawnictwo Nauka i Innowacje, Poznań.

Lofland John i in., 2009, Analiza układów spotecznych. Przewodnik metodologiczny po badaniach jakościowych, tłum. Anna Kordasiewicz, Sylwia Urbańska, Monika Żychlińska, Scholar, Warszawa.

Łukasiuk Magdalena, 2012, Metoda autoetnograficzna $w$ socjologii emocji, „Societas/Communitas”, nr 2(14).

Manterys Aleksander, 1997, Wielość rzeczywistości w teoriach socjologicznych, Państwowe Wydawnictwo Naukowe, Warszawa.

Merleau-Ponty Maurice, 2015, Fenomenologia percepcji, tłum. Kowalska Małgorzata, Jacek Migański, Aletheia, Warszawa.

Mills Charles Wright, 2007, Wyobraźnia socjologiczna, tłum. Marta Bucholc, Wydawnictwo Naukowe PWN, Warszawa.

Mokrzycki Edmund (red.), 1984, Kryzys i schizma. Antyscjentystyczne tendencje w socjologii wspótczesnej, 2 t., PIW, Warszawa.

Mokrzycki Edmund, 2007, Do nauki przychodzi się nie tylko z pytaniami, IFiS PAN, Warszawa. 
Olejnik Marta A., 2007, „Komunikacyjne sposoby utwierdzania się we wspólnej wizji rzeczywistości", niepublikowana praca magisterska pod kierownictwem dr. Sławomira Mandesa, IS UW, Warszawa.

Oliwińska Iwona A., 2008, Warszawskie Szmulki. Miejsca, ludzie, style życia, Wydawnictwo Żak, Warszawa.

Ossowski Stanisław, 2001, O osobliwościach nauk społecznych, Wydawnictwo Naukowe PWN, Warszawa.

Popper Karl R., 1985, Socjologia wiedzy, tłum. Andrzej Chmielecki, w: Andrzej Chmielecki i in. (red.), Problemy socjologii wiedzy, Państwowe Wydawnictwo Naukowe, Warszawa.

Rabinow Paul, 1999, Wyobrażenia sa faktami spotecznymi: modernizm $i$ postmodernizm $w$ antropologii, tłum. Joanna Krzemień, w: Michał Buchowski, Marian Kempny (red.), Amerykańska antropologia postmodernistyczna, Instytut Kultury, Warszawa.

Rakoczy Marta, 2014, Szkoła, pismo, praktyka w świetle zwrotu performatywnego, „Tematy z Szewskiej”, nr 2 (12), s. 6-19.

Rakowski Tomasz, 2009, Łowcy, zbieracze, praktycy niemocy. Etnografia człowieka zdegradowanego, Słowo/obraz terytoria, Gdańsk.

Rakowski Tomasz (red.), 2013, Etnografia/Animacja/Sztuka: nierozpoznane wymiary rozwoju kulturalnego, Narodowe Centrum Kultury, Warszawa.

Rorty Richard, 2009, Filozofia jako polityka kulturalna, tłum. Bogdan Baran, Czytelnik, Warszawa.

Rorty Richard, 2013, Filozofia a zwierciadło natury, tłum. Michał Szczubiałka, Wydawnictwo KR, Warszawa.

Schütz Alfred, 1984, Potoczna i naukowa interpretacja ludzkiego dziatania, tłum. Dorota Lachowska, w: Mokrzycki Edmund (red.), Kryzys i schizma. Antyscjentystyczne tendencje w socjologii wspótczesnej, t. 1, PIW, Warszawa.

Silvermann David, 2010, Prowadzenie badań jakościowych, tłum. Joanna Ostrowska, Wydawnictwo Naukowe PWN, Warszawa.

Sobota Daniel R., 2012, Źródła i inspiracje Heideggerowskiego pytania o bycie, t. 1: Neokantyzm i fenomenologia, Fundacja Kultury Yakiza, Bydgoszcz.

Szacki Jerzy, 1977, Czy kryzys socjologii?, Czytelnik, Warszawa.

Touraine Alain, 2010, O socjologii, tłum. Michał Warchala, Wydawnictwo Naukowe PWN, Warszawa.

Walczak Bartłomiej, 2009, Antropolog jako Inny. Od pierwszych badań terenowych do wyzwań ponowoczesnej antropologii, Scholar, Warszawa.

Walczak Bartłomiej, 2013, Zwrot lingwistyczny a samorefleksyjność antropologii, „Przegląd Socjologii Jakościowej", t. 9, nr 3, s. 110-123.

Weber Max, 1985a, „Obiektywność” poznania w naukach społecznych, tłum. Mirosław Skwieciński, w: Andrzej Chmielecki i in. (red.), Problemy socjologii wiedzy, Państwowe Wydawnictwo Naukowe, Warszawa, s. 45-100.

Weber Max, 1985b, Sens „uwolnienia od wartościowañ w socjologii i ekonomii, tłum. Elżbieta Nowakowska-Sołtan, w: Andrzej Chmielecki i in. (red.), Problemy socjologii wiedzy, Państwowe Wydawnictwo Naukowe, Warszawa, s. 101-148.

White Alasdair, 2008, From Comfort Zone to Performance Management: Understanding Development and Performance, White \& MacLean Publishing.

Wyka Anna, 1993, Badacz społeczny wobec doświadczenia, IFiS PAN, Warszawa.

Znaniecki Florian, 2009, Metoda socjologii, tłum. Elżbieta Hałas, Wydawnictwo Naukowe PWN, Warszawa. 
ON THE AUTOETHNOGRAPHY OF TOUCHES, WOUNDS, AND DEFORMATIONS

Katarzyna Kalinowska

(University of Lodz)

\section{Summary}

The author presents autoethnography as a systematic research method used in field studies into the emotions of love. She begins by tracing various sociological and anthropological approaches and noting the place they give to an active, subjective researcher with agency. Then she concentrates on how autoethnographic data is generated and used in the course of the research process. In her opinion, autoethnography can be an original source of data-a supplement and verification for other materials collected in the field -if the personal experiences of the researcher are treated with the same attention as the experiences of the persons studied. She proposes to verify these experiences and the researcher's activities in the world by use of the "clinical" and analytic autoethnographic method, which relies on the strategy of the "researcher as a tool." This concept corresponds to the figure of the "vulnerable observer" used by researchers of the school of evocative autoethnography; it turns the researcher's personal biography into a unit of analysis.

\section{Key words / słowa kluczowe}

autoethnography / autoetnografia, researcher as a tool / badacz jako narzędzie, vulnerable observer / badacz podatny na zranienie, analytic autoethnography / autoetnografia analityczna, evocative autoethnography / autoetnografia ewokatywna 